\title{
Investigation of Main Planktonic Foraminiferal Bio-Events in Surgah Formation at Pol-e-Dokhtar Area, South Western of Iran
}

\author{
M. Vahidinia*, M. Haddadi, M. Shafiee Ardestani \\ Department of Geology, Faculty of Science, Ferdowsi University of Mashhad, Mashhad, Iran \\ Email: *vahidinia@ferdowsi.um.ac.ir
}

Received 11 June 2016; accepted 15 August 2016; published 18 August 2016

Copyright (C) 2016 by authors and Scientific Research Publishing Inc.

This work is licensed under the Creative Commons Attribution International License (CC BY). http://creativecommons.org/licenses/by/4.0/

(c) (i) Open Access

\section{Abstract}

Surgah Formation at Male-kuh well section with 82 meters thickness has been studied at Pol-eDokhtar area. Surgah Formation at mentioned section was composed of limestone and shaly limestone. The lower and upper contacts of studied formation with Sarvak and Ilam formations are conformed. Based planktonic foraminifera study 37 species belonging to 10 genera in frame of two planktonic foraminiferal biozones were identified respectively as below: 1) Dicarinella concavata Interval Zone; 2) Dicarinella asymetrica Total Range Zone. Finally, based on recent investigation have been detected middle Turonian-Late Santonian age for studied section. According to (Robaszynski and Caron 1979), the first occurrence of Dicarinella primitiva has been shown base of the Coniacian stage. The first occurrence of Di. primitiva was placed under the Turonian-Coniacian boundary. Robaszynski and Caron 1995 recorded the first occurrence of Dicarinella primitiva and Dicarinella concavata were simultaneous and assigned to late Turonian which correlated with ammonite's species Subprionocyclus neptuni. In the correlation between ammonite and Dicarinella primitiva at Tethyan realm first occurrence of Di. primitiva was close to the Middle-Late Turonian sub stage. The base of Coniacian stage was identified based on the FODs of Archaeoglobigerina cretacea and Dicarinella concavata from planktonic foraminifera with FOD of Cremnoceramus walterdorfensis walterdorfensis from inoceramid group, while the base of Santonian stage recorded using LOD of Dicarinella primitiva, Whiteinellids group with FODs of Dicarinella asymetrica and Inoceramus aff. vistulensis (inoceramid species).

\section{Keywords}

Zagros Sedimentary Basin, Surgah Formation, Male-Kuh Section, Biostratigraphy,

\footnotetext{
*Corresponding author.
}

How to cite this paper: Vahidinia, M., Haddadi, M. and Ardestani, M.S. (2016) Investigation of Main Planktonic Foraminiferal Bio-Events in Surgah Formation at Pol-e-Dokhtar Area, South Western of Iran. Open Journal of Geology, 6, 774-785. http://dx.doi.org/10.4236/ojg.2016.68060 


\section{Planktonic Foraminifera}

\section{Introduction}

The study area is located in the North East Zagros Basin. Zagros folded and thrust belt is considered as part of the Alpine-Himalaya Mountains [1]. It is $2000 \mathrm{~km}$ in length, from the northwest (southeast Turkey) to the southeast (Oman line) [2].

This tectonic zone is characterized by three regions: 1) Uremiah-Dokhtar magmatic assemblage; 2) Zagros imbricate zone; 3) Zagros folded and thrust belt [3]. Present-day Iran is part of the Alpine-Himalayan orogenic belt, which is bordered by the Arabian Shield to the southwest and the Turan Plate to the northeast (Figure 1).

The zagros orogenic belt of Iran, as part of the Alpine-Himalayan mountain chain, extends for about $2000 \mathrm{~km}$ in a NW-SE direction from the East Anatolian Fault of eastern Turkey to the Oman Line in southern Iran. The belt is considered to be a complex product of an early Mesozoic separation of the Iranian continental block from the rest of the Gondwana Indmass(es) followed by a NE-dipping subduction of the newly generated Neo-Tethyan oceanic crust below the Iranian microcontinent and subsequent collision between the Afro-Arabian and Iranian plates [4]-[12]. More than 65 percent (107.5 billion cubic meters) of the remaining proven oil reserves (159.6 billion cubic meters) and nearly 34 percent (49.5 trillion cubic meters) of the total gas reserves (146.4 trillion cubic meters) of the world have accumulated in numerous giant and supergiant hydrocarbon fields of the Middle East [3].

Zagros sedimentary basin with high quantity of oil and gas attracted many geologists many years ago. In spite of Shiraz district which deposition is combimused from jurassic bill cretaceous sea. All of Zagros crataceous rock have not same facies and deposited at various position [13]. Lorestan province has been existed deep condibion at Coniacian stage which was deposited Surgah Formation at lower contact of Ilam Formation [14]. At Zagros sedimentary basin in Albiat untill Companian stage has been deposited respectively Kajdomi, Sarvak, Surgah and Ilam Formation which mentianed Formations made a Bangestan group [15]. Type Locality of Surgah Formation was placed in Tang-e-Grab at southwestern Surgah montain and $12 \mathrm{~km}$ from southwestern of Ilam country. It has 175.5 meters thickness with main lithological units of lght to drak gray shales with intracalted fine limestone [14]. Surgah Formation has been inreslcigated for many times.

Wynd in 1965 has recored Coniacian age for Surgah Formation in Zagros sedimentary basin. Also [19] have detected same age for it like Wynd. [20] have been detected Late Turonian-Late Santonian ages for Surgah Formation type section. [21] recognized Late Turonian-late Santonian ages for Surgah Formation at Kuh-e-Shah nakhjir section based on planktonic foraminifera. The main goal of this research work is precise stratigraphy of the Sourgah Formation at Maleh-Kuh section by using planktonic foraminifera.

\section{Lithology and Geographical Position}

The Surgah Formation was defined by [22] (Figure 2). The type section of the formation is at the north-western part of the KabirKuh Anticline at Tang-e Garab in Lurestan. In the type section, the Surgah Formation is composed of $176 \mathrm{~m}$ of grey to dark grey, pyritic, low-weathering shale with subordinate yellow-weathering, thinbedded limestone of Turonian to Early Santonian age [15]. The Surgah Formation is well developed only in the Lurestan area. In the Dezful embayment, it is questionably represented in the Ab-e Teymur and Darquain oil welds by a thin interval of shale beds between the Sarvak and Ilam formations [23].

Maleh-kuh ohl field has been deposited in asymentrical surface anticline with NW-SE trend. Mentioned field has been placed at $130 \mathrm{~km}$ of Andimeshk.Maleh-kuh (well no.1) at Pol-e-Dokhtar country near the Kashkan river. For access to the mentioned section we must pass $7 \mathrm{~km}$ from the pol-e-dokhtar country to the Babazeyd road and after reached and passed of $4 \mathrm{~km}$ we reach to the studied section. This well has $33^{\circ} 12^{\prime 2} 28^{\prime \prime}$ and $47^{\circ} 42^{\prime} 17^{\prime \prime}$ geographical position. Sourgah Formation at type locality has 175.5 meters thickness and consists of dark to light grey shale with some fine limestone. This formation at Maleh-kuh section has 82 meters thickness with main lithological unites of shales, limestone and shaley limestone with pyrite and glaqunite. Also Sourgah Formation at studied section consists of 9 lithological unites respectively as follows:

1) Dark brown shaly limestone, $5 \mathrm{~m}$ thick.

2) Light gray lime stone, $2.5 \mathrm{~m}$ thick. 

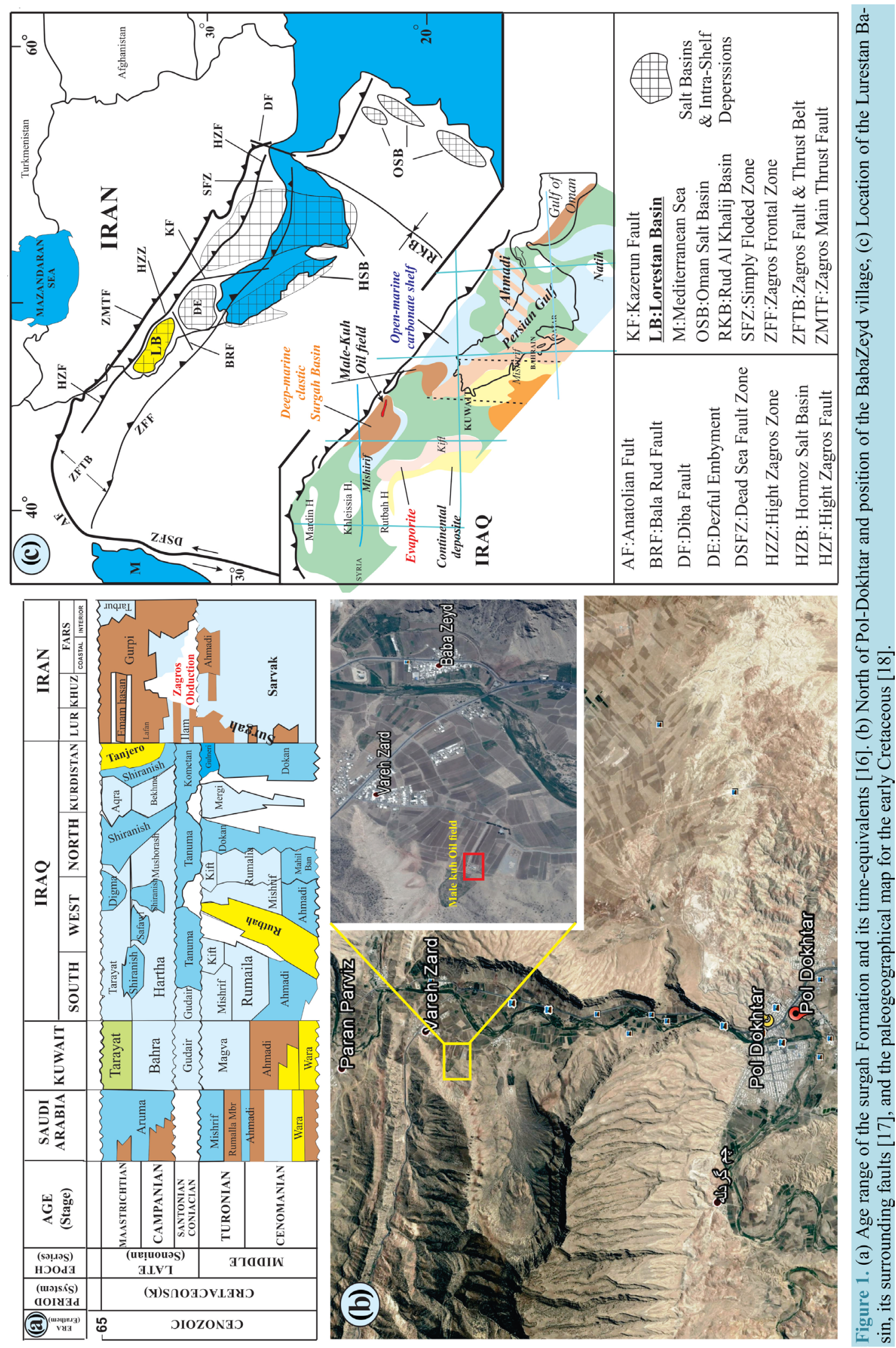

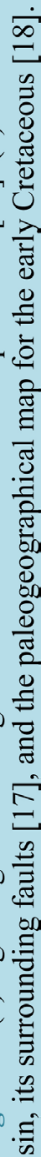




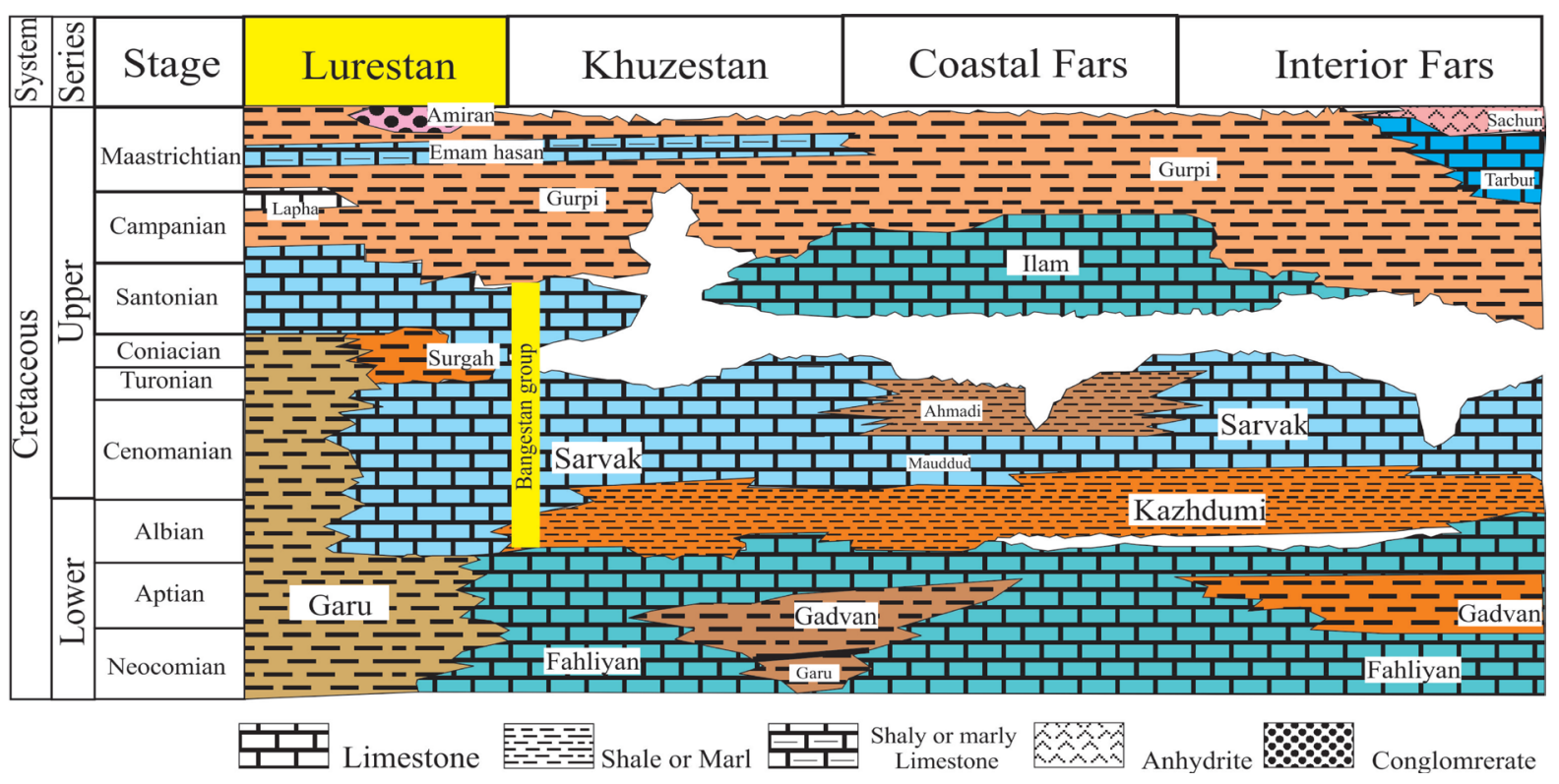

Figure 2. Correlation chart of Cretaceous strata, Zagros basin, Iran (adapted from [15]).

3) Brown shaly limestone, $12.5 \mathrm{~m}$ thick.

4) Dark brown to brown shale with accompany of pyrite and glaqunite, $37 \mathrm{~m}$ thick.

5) Dark brown shaly limestone, $3 \mathrm{~m}$ thick.

6) Brown shale, $5 \mathrm{~m}$ thick.

7) Gray to dark brown shaly limestone, $10 \mathrm{~m}$ thick.

8) Dark gray limestone, $2.5 \mathrm{~m}$ thick.

9) Dark brown shaly limestone, $4.5 \mathrm{~m}$ thick.

\section{Material and Method}

In this research 54 samples from the Male-Kuh section with 1.5 meters distances have been gathered. Ultimately after preparation and study of all thin sections 2 planktonic foraminiferal plates were made (Plate 1 \& Plate 2).

\section{Discossion}

\section{Biostratigraphy}

The planktonic foraminiferal zonation here used is compared in Figure 3 with other Tethyan biozonations [22] [24]-[33]. This zonation is similar to that of Premoli-silva and Verga, 2004. Surgah Formation at Maleh-kuh section has 82 meters (1408 m - $1326 \mathrm{~m})$ thickness and have been consist of shale with intracalated of limestone and shaly limestone with accompany of pyrite and glauconite. In this research 37 planktonik foraminiferal species have been identified belonging to 10 genera inframe of three biozones (Figure 3). In this research these references have been used for planktonic foraminifera recognition such as the below: [34]-[39] (Figure 4). Based of this study have been recorded Late middle Turonian-upper Santonian for mentioned section. According to the recent researches first occurrence of Cremnoceramus deformis erectus was shown base of the Coniacian stage in the world. Also heed to recently research which was ratified first occurrence were placed under the FO of Cremnoceramus deformis erectus (Meek 1918 [40]-[42]. Therefore has been considered late Turonian and uppermost Turonian ages respectively for FO of Dicarinella primitiva and Dicarinella concavata.

In this investigation have been used of composed biozonation of [33].

At this research were recognized of two biozones such as below:

\section{Dicarinella concavata Zone}

Category: Interval Zone

Age: Late Turonian to earliest Santonian

Author: Sigal (1995) 
This zone has been introduced for the first time by Sigal in 1955 and he assigned the Late Coniacian to Early Santonian for the Dicarinella concavata Interval Range Zone. According to Premoli-Silva and Verga, 2004 D.concavata biozone has been shown uppermost Turonian to earliest Santonian. [33] [43] [44] assigned the Dicarinella concavata Interval Range Zone to Upper Turonian. The range of the Dicarinella concavata is from the Upper Coniacian to Lower Santonian according to [30]-[37] assigned the Coniacian stage for this zone.

This biozone has been detected between $1393 \mathrm{~m}$ - $1365 \mathrm{~m}$ and has 27.5 meters thickness with main lithological units such as shale and shaley limestone and was begin from first occurrence of Dicarinella concavata to first occurrence Dicarinella asymetrica. All of planktonic foraminiferal species were found at this zone are as below:

Archaeoglobigerina cretacea (d'Orbigny), Dicarinella algerina (Caron), Dicarinalla concavata (Brotzen), Globotruncana lapparenti (Brotzen), Heterohelix globulosa (Ehrenberg), Macroglobigerinelloides ultramicrus (Subbotina), Macroglobigerinelloides sp., Marginotruncana coronata (Bolli), Marginotruncana marginata
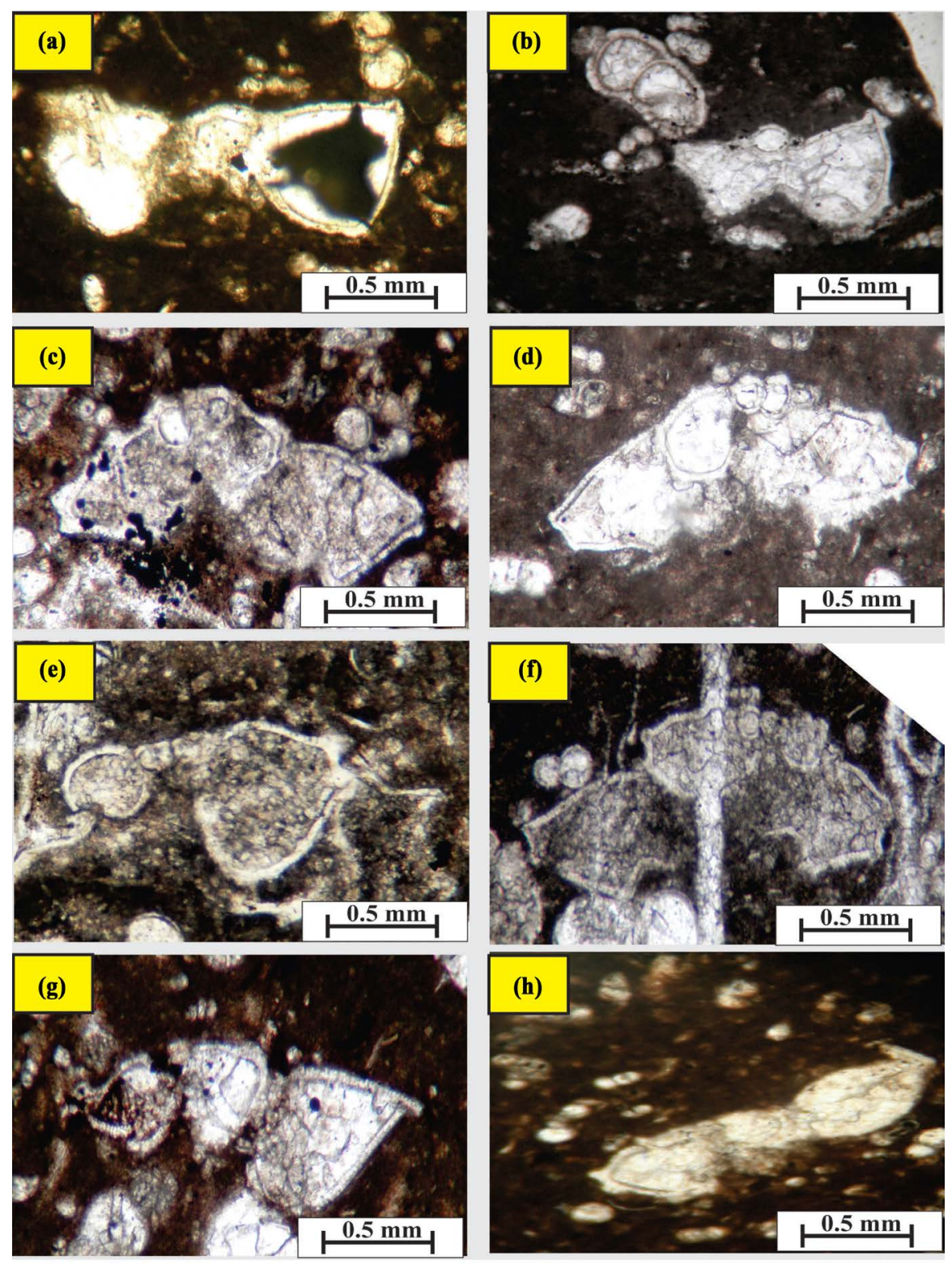

Plate 1. (a) Dicarinella asymetrica (Sigal, 1952); (b) Dicarinella concavata (Brotzen, 1934); (c) Marginotruncana sigali (Reichel, 1950); (d) Globotruncana arca (Cushman, 1926); (e) lobotruncana hilli (Pessagno, 1967); (f) Marginotruncana schneegansi (Sigal, 1952); (g) Marginotruncana renzi (Gandolfi, 1924); (h) Dicarinella primitiva (Dalbiez, 1955). 

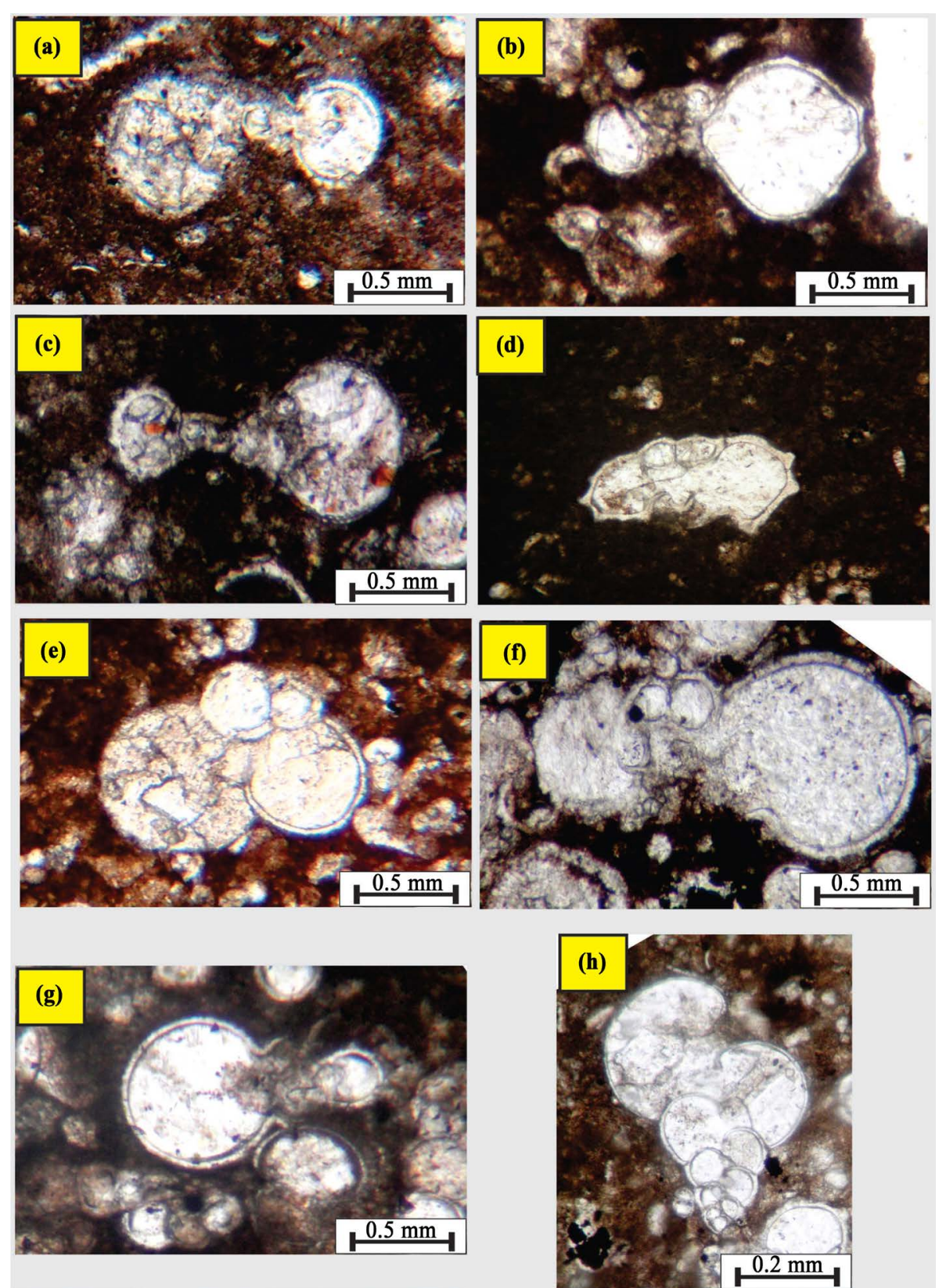

Plate 2. (a) Muricohedbergella planispira (Tappan, 1940); (b) Archaeoglobigerina cretacea.(d’Orbigny, 1840); (c) Macroglobigerinelloides bolli (Pessagno, 1967); (d) Globotruncana lapparenti (Brotzen. 1936); (e) Whiteinella paradubia (Sigal, 1952); (f) Whiteinella baltica (Douglas\&Rankin, 1969); (g) Macroglobigerinelloides caseyi (Bolli, Loeblich \& Tappan, 1957) (h) Heterohelix globulosa (Ehrenberg, 1840).

(Reuss), Marginotruncana pseudolinneiana (Pessagno), Marginotruncana renzi (Gandolfi), Marginotruncana schneegansi (Sigal), Marginotruncana sigali (Reichel), Marginotruncana of sinuosa, (porthault), Muricohedbergella planispira (Tappan), Whiteinella paradubia (Sigal),

\section{Dicarinella asymetrica Zone}

Category: Total Range Zone

Age: Early Santonian to earliest Campanian

Author: Postuma (1971)

This Zone has been introduced for the first time by [26] and was shown early Santonian-late Santonian age. Also mentioned biozone was detected from deep 1365.5 till 1326 meters and has 39.5 meters thickness with 


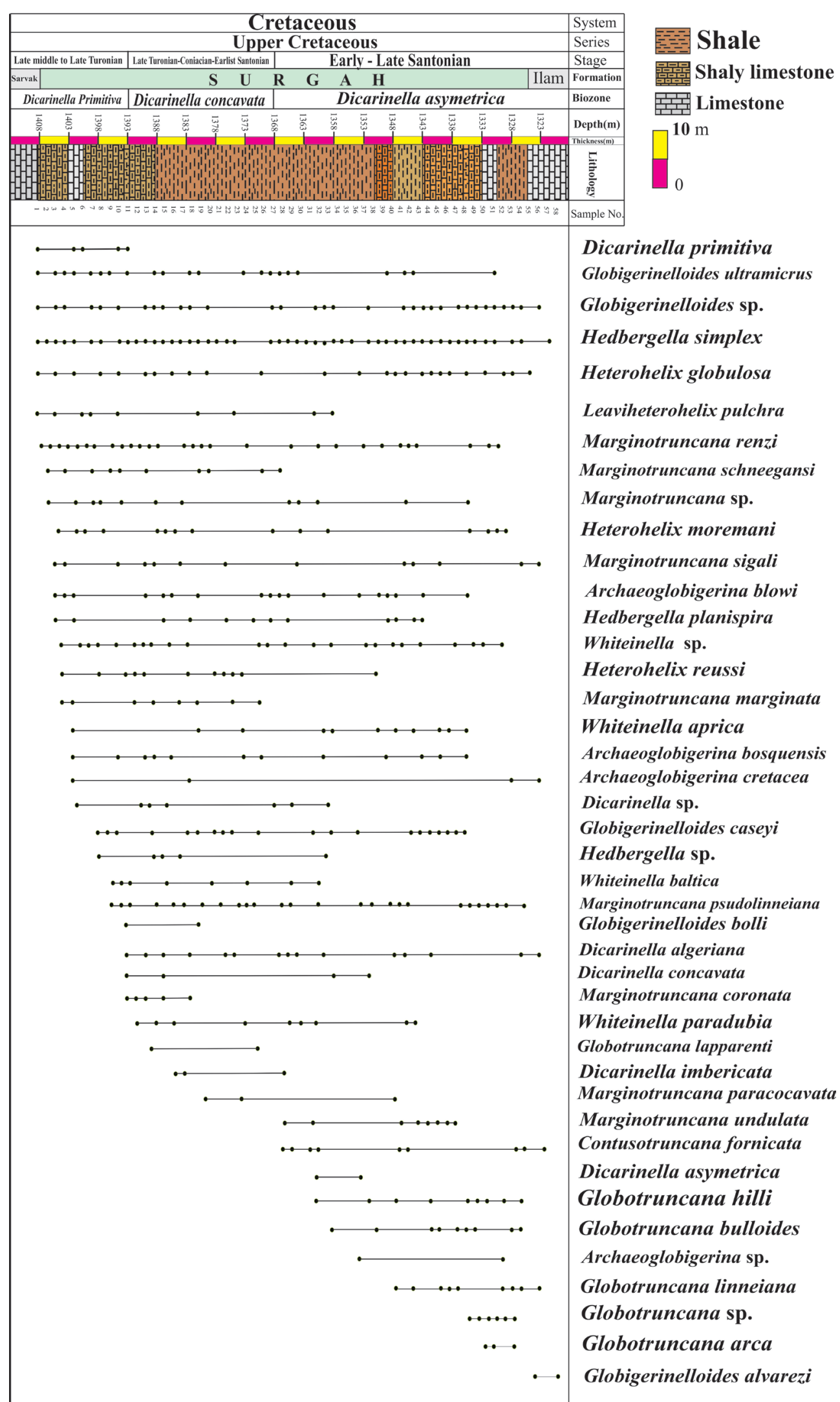

Figure 3. Distribution and planktonic foraminiferal zonation of the Surgah Formations at Malehkuh oil field. (Well no. 1). 


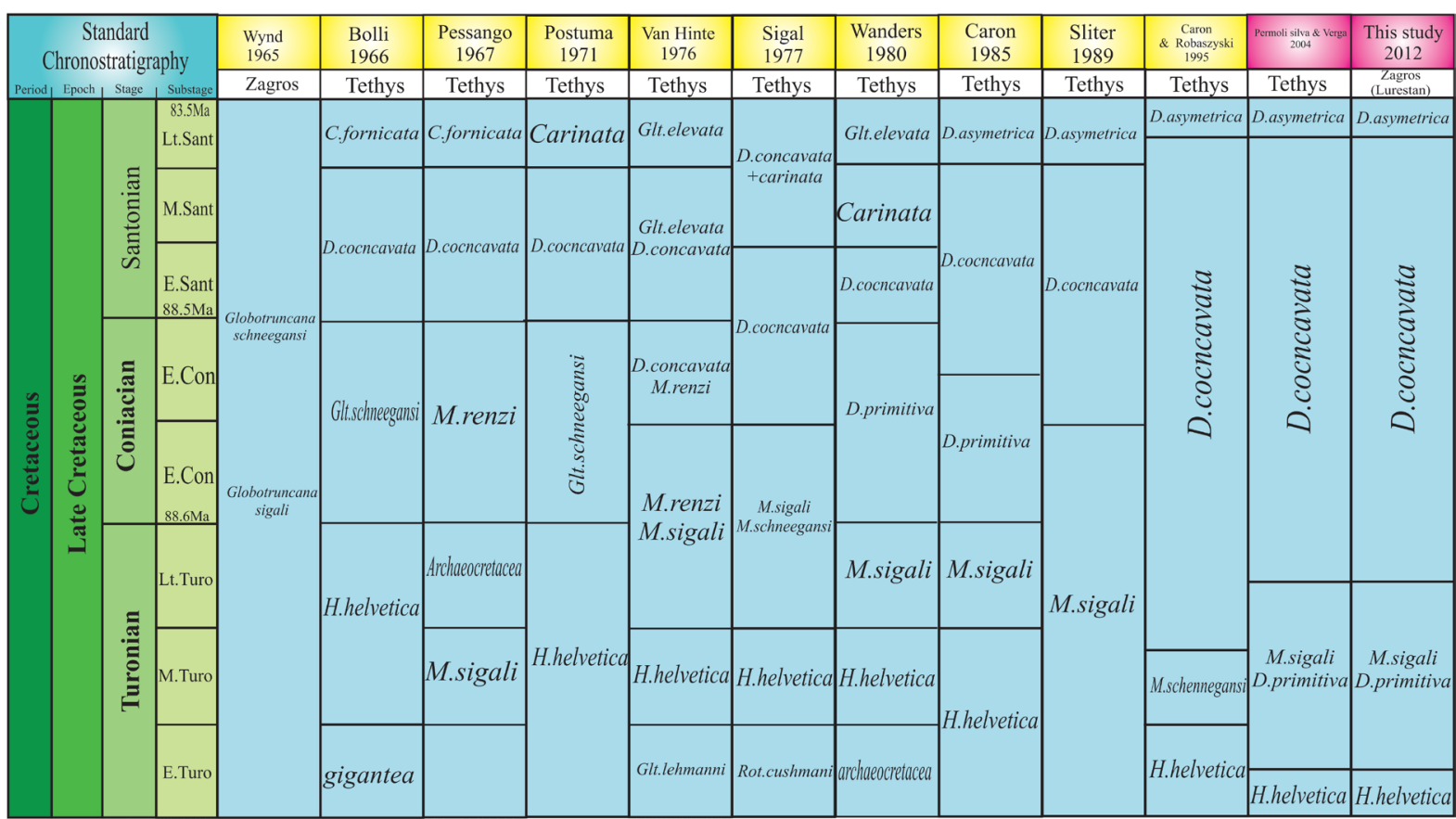

Figure 4. Correlation of the proposed biostratigraphic zonal scheme at this study with other accepted standard biozones of other parts of the world.

shale to shaley limestone lithological units. Globotruncanita elevata and Globotruncanita stuartiformis were not found at this zone and Dicarinella asymetrica was not extinct. Therefore age of this biozone is early-late Santonian in this area. All of the main planktonic foraminiferal species were found at this Zone are as below:

Archaeoglobigerina bosquensis (Pessagno), Contusotruncana fornicate (Plummer), Dicarinella asymetrica, (Sigal), Dicarinalla concavata, (Brotzen), Globutruncana arca (Cushman), Heterohelix globulosa (Ehrenberg), Laeviheterohelix pulchra (Brotzen), Macroglobigerinelloides alvarezi (Eternod olvera), Marginotruncana coronata (Bolli), Marginotruncana marginata (Reuss), Muricohedbergella planispira (Tappan), Whiteinella baltica (Douglas \& Rankin), Whiteinella sp.

\section{Turonian-Coniacian (T/C) boundary}

[45] recorded the first occurrence of ammonite species Prionocycloceras milticostatum as index species for the Turonian-Coniacian boundary. The majority of planktonic foraminifera researchers have believed that Turonian-Coniacian boundary cannot be determined based on planktonic foraminifera, but some others believed that the first occurrence of Marginotruncana sinuosa has been shown in Turonian-Coniacian boundary [41] [46] [47]. Also [45] introduced a supplementary planktonic foraminifera specie with name of Muricohedbergella flandrini which was used if Dicarinella primitiva do not exist. Also some authors described last occurrence of some planktonic foraminifer's species such as Muricohedbergella simplex and Dicarinella primitiva took place before the first occurrence of Dicarinella concavata [48]. But today first occurrence of one inoceramids species, Cremnoceramus deformis erectus has been used for identification of the Turonian-Coniacian boundary [49]-[53]. In a major symposium about Cretaceous boundaries held in Brussels in 1995, FAD C.deformis erectus was used as the first marker species for of the base of the Coniacian stage. Also FAD Cremnoceramus deformis deformis were shown lower Coniacian stage in the world [54]. In studied area first occurrence of Dicarinella primitiva was shown the upper Turonian sub stage. Also first occurrence of Marginotroncana paraconcavata has been shown Coniacian-Santonian boundary [30], in the study area FO of M. paraconcavata took place at Dicarinella primitiva Interval Range Zone (upper Turonian). Marginotruncana paraconcavata and Costellagerina pilula indicate the Turonian-Coniacian boundary in Iran.

Recently the First occurrence of Cremnoceramus rotundatus, an inoceramid bivalve, was recommended for defining the Turonian-Coniacian boundary by the Coniacian working group (CWG) of the Cretaceous subcomission on stratigraphy [41]. First occurrence of Cremnoceramus deformis erectus was the primary marker for realizing Turonian-Coniacian boundary in the world [41] [51] [52]. According to recording FO of Dicarinella 
concavata and Dicarinella primitiva below of the FO of Cremnoceramus deformis deformis, in the study section so, upper Turonian sub stage assigned to the Dicarinella concavata Interval Zone in the study area. Consequently Turonian-Coniacian and Coniacian-Santonian boundaries have been placed in this zone.

\section{Coniacian-Santonian (C/S) boundary}

The first occurrence of inoceramid species, Cladoceramus undulatoplicatus was index species for realized the Coniacian-Santonian boundary [55]-[62]. The Santonian Working Group (SWG) recommends the lowest occurrence of Cladoceramus undulatoplicatus as the marker for the Coniacian-Santonian boundary. As yet, the SWG cannot make a formal proposal for a Boundary Stratotype Section, because the biostratigraphy must be better known and integrate first. Three candidates for Boundary Stratotype Section, Olazagutia Quarry (Navarra, Spain), Seaford Head (Sussex, England) and Ten Mile Creek (Dallas, Texas, USA), were selected for further decision. Primary marker: The lowest occurrence of Cladoceramus undulatoplicatus. It is a taxon easily recognizable and widespread. It is known in N. America, Europe, Africa, Madagascar, and Central Asia.

Secondary marker: Sigalia carpatica. This planktonic foraminiferan is widespread in the Mediterranean Region of the Tethys. It is associated with Inoceramus siccensis and Texanites in Tunisia. In north Spain (Navarra) it is very close to the lowest occurrence of Cladoceramus undulatoplicatus. In the studied area Cladoceramus undulatoplicatus have not been recorded, therefore the first occurrence of Echinocurys gr. scutata as a secondary marker [56] used to realized C/S boundary and finally according to the Fos of E. gr. scutata, and pill box globotruncana linneiana (planktonic foraminifera) Coniacian-Santonian has been detected.

\section{Conclusions}

Surgah Formation has been studied at Male-Kuh section in southwestern of Iran. Thirty seven planktonic foraminifers of 2 biozones have been recorded as below:

1) Dicarinella concavata Interval Zone; 2) Dicarinella asymetrica Total Range Zone.

Based on this research, late middle Turonian-late Santonian ages were detected of mentioned studied section. Finally all of realized biozons in this research have been compared with main Tyetyan biozonation scheme in the world and all of zones which were identified for Surgah Formation at Maleh-Kuh section resembles with Permoli-Silva \& Verga 2004 biozonation.

\section{Acknowledgements}

This research was funded by Ferdowsi University of Mashhad. The authors would like to express their deep gratitude Dr. Amiri Bakhtiar for his invaluable helps during the study. The study is proudly dedicated to the living memory of Professor Cushman.

\section{References}

[1] Alavi, M. (1994) Tectonics of the Zagros Orogenic Belt of Iran: New Data and Interpretation. Tectonophysics, 229, 211-238. http://dx.doi.org/10.1016/0040-1951(94)90030-2

[2] Falcon, N.L. (1969) Problems of the Relationship between Surface Structure and Deep Displacements Illustrated by the Zagros Range. Geological Society Special Publication, London, 3, 9-22.

[3] Alavi, M. (2007) Structures of the Zagros Fold-Thrust Belt in Iran. American Journal of Science, 307, 1064-1095. http://dx.doi.org/10.2475/09.2007.02

[4] Takin, M. (1972) Iranian Geology and Continental Drift in the Middle East. Nature, 235, 147-150. http://dx.doi.org/10.1038/235147a0

[5] Crawford, A.R. (1972) Iran. Continental Drift and Plate Tectonic 24th, Geol., Montreal, Sect, 3, 106-112.

[6] Dewey, J.F., Pitman, W., Ryan, W. and Bonin, J. (1973) Plate Tectonics and the Evolution of the Alpine System. Geological Society of America Bulletin, 84, 3137-3180. http://dx.doi.org/10.1130/0016-7606(1973)84<3137:PTATEO>2.0.CO;2

[7] Haynes, S.J. and McQuillan, H. (1974) Evolution of the Zagros Suture Zone, Southern Iran. Geological Society of America Bulletin, 85, 739-744. http://dx.doi.org/10.1130/0016-7606(1974)85<739:EOTZSZ>2.0.CO;2

[8] Pamic, J., Sestini, G. and Adib, D. (1979) Alpine Magmatic and Metamorphic Processes and Plate Tectonics in the Zagros Range, Iran. Geological Society of America Bulletin, 90, 569-576.

http://dx.doi.org/10.1130/0016-7606(1979)90<569:AMAMPA>2.0.CO;2 
[9] Alavi, M. (2004) Regional Stratigraphy of the Zagros Fold-Thrust Belt of Iran and Its Proforeland Evolution. American Journal of Science, 304, 1-20. http://dx.doi.org/10.2475/ajs.304.1.1

[10] Berberian, M. and King, G.C.P. (1981) Towards a Paleogeography and Tectonic Evolution of Iran. Canadian Journal of Earth Sciences, 18, 210-265. http://dx.doi.org/10.1139/e81-019

[11] Sengör, A.M.C. (1984) The Cimmeride Orogenic System and the Tectonics of Eurasia. Geological Society of America, Special Paper, 195.

[12] Vahidinia, M., Youssef, M., Shafiee Ardestani, M., Sadeghi, A. and Dochev, D. (2014) Integrated Biostratigraphy and Stage Boundaries of the Abderaz Formation, East of the Kopeh-Dagh Sedimentary Basin, NE Iran. Journal of African Earth Sciences, 90, 87-104. http://www.sciencedirect.com/science/journal/1464343X/90/supp/C

[13] Motiei, H. (2003) Geology of Iran (Stratigraphy of Zagrus). Publication of Geosciences, 583 p.

[14] Motiei, H. (1994) Stratigraphy of Zagrus. Geological Survey of Iran, 563 p.

[15] James, G.A. and Wynd, J.G. (1965) Stratigraphy Nomenclature of Iranian Oil Consortium Agreement Arca. AAPG Bulletin, 49, 2182-2245.

[16] Al-Husseini, M.I. (2000) Origin of the Arabian Plate Structures: Amar Collision and Najd Rift. GeoArabia, 5, 527-542.

[17] Heydari, E. (2008) Tectonic versus Eustatic Control on Supersequences of the Zagros Mountains of Iran. Tectonophysics, 451, 56-70. http://dx.doi.org/10.1016/j.tecto.2007.11.046

[18] Van Buchem, F.S.P., Baghbani, D., Bulot, L.G., Caron, M., Gaumet, F., Hosseini, A., Keyvani, F., Schroeder, R., Swennen, R., Vedrenne, V. and Vincent, B. (2010) Barremian-Lower Albian Sequence Stratigraphy of Southwest Iran (Gadvan, Dariyan, and Kazhdumi Formations) and Its Comparison with Oman, Qatar and the United Arab Emirates. In: Van Buchem, F.S.P., Al-Husseini, M.I., Maurer, F. and Droste, H.J., Eds., Barremian-Aptian Stratigraphy and Hydrocarbon Habitat of the Eastern Arabian Plate, Vol. 2, GeoArabia Special Publications 4, Gulf Petro Link, Bahrain, 503-548.

[19] Ghiasvand and Ghasemi-Nejad (2003) Biostratigraphy and Bio-Correlation of Bangestan Group at Sarkan and Maleh-Kuh Oil Fields. MSc Dissertation, University of Tehran, Tehran, 118 p.

[20] Monjezi, N. and Moghaddam, V. (2010) Biostratigraphy of Surgah Formation (Type Section) at Southwestern of Ilam, Based on Planktonic Foraminifera. MSc Dissertation, Isfahan University, Isfahan, 95 p.

[21] Raziani, M. and Sadeghi (2010) Lithostratigraphy and Biostratigraphy of Sourgah and Ilam Formations at Kuhshah e Nakhjir and Compare Them with Type Section. MSc Thesis, Shahid Beheshti University, Tehran, 272 p.

[22] Wynd, J.G. (1965) Biofacies of the Iranian Oil Consortium Agreement Area. IOOC Report, No. 1028. (Unpublished)

[23] Desbordes, H.B. (1972) Preliminary Subsurface Study of the Bangestan Limestone, South Khuzestan: Iran. Oil Service Company of Iran Technical Memoir 116, Tehran. (Unpublished)

[24] Bolli, H.M. (1966) Zonation of Cretaceous to Pliocene Marine Sediments Based on Planktonic Foraminifera. Boletin Informativo Asociacion Venezolana de Geologia, Mineria y Petroleo, 9, 3-32.

[25] Pessango Jr., E.A. (1967) Upper Cretaceous Planktonic Foraminifera from the Western Gulf Coastal Plain. American Journal of Paleontology, 5, 259-441.

[26] Postuma, J. (1971) Manual of Planktonic Foraminifera. Elsevier Publishing Co., Amsterdam, 420.

[27] Van Hinte, J.E. (1976) A Cretaceous Time Scale. Bulletin of the American Association of Petroleum Geologists, 60, 498-516.

[28] Sigal, J. (1977) Essaide zonation du cretace mediteeraeen an aide des foraminifer’s planctoniques. Geologie Mediterraneenne, 4, 99-108.

[29] Wonders, A.A. (1980) Middle \& Late Cretaceous Planktonic Foraminifera of the Western Mediterranean Area. Utrecht Micropaleontological Bulletins, 24, 1-158.

[30] Caron, M. (1985) Cretaceous Planktic Foraminifera. In: Bolli, H.M., Saunders, J.B. and Perch Nielsen, K., Eds., Plankton Stratigraphy, Cambridge University Press, Cambridge, 17-86.

[31] Sliter, W.V. (1989) Biostratigraphic Zonation for Cretaceous Planktonic Foraminifers Examined in Thin Section. The Journal of Foraminiferal Research, 19, 1-19. http://dx.doi.org/10.2113/gsjfr.19.1.1

[32] Robaszynski, F. and Caron, M. (1995) Foraminifers planktonique du cretace. Bulletine Society Geological of France, 166, 681-698.

[33] Premoli Silva, I. and Verga, D. (2004) Practical Manual of Cretaceous Planktonic Foraminifera. In: Verga, D. and Rettori, R., Eds., International School on Planktonic Foraminifera, Universities of Perugia \& Milano, Tipografia Pontefelcino, Perugia, 283.

[34] Bolli, H.M. (1957) The Genera Praeglobotruncana, Globotruncana, Rotalipora, Abathomphalus in the Upper Creta- 
ceous of Trinidad, B.W.I. Bulletin—United States National Museum, 215, 51-60.

[35] Sliter, W.V. and Baker, R.A. (1972) Cretaceous Bathymetric Distribution of Benthic Foraminifera. The Journal of Foraminiferal Research, 2, 167-183. http://dx.doi.org/10.2113/gsjfr.2.4.167

[36] Robaszynski, F. and Caron, M. (1979) Atlas de foraminife`rs planctoniques du Crétace' moyen (Mer Boreale et Tethys), premie repartie. Cahiers de Micropaleontologie, 1, 1-185.

[37] Premoli Silva, I. and Sliter, W.V. (1995) Cretaceous Planktonic Foraminiferal Biostratigraphy \& Evolutionary Trends from the Bottaccione Section, Gubbio, Italy. Palaeontographia Italica, 82, 1-89.

[38] Vaziri-Moghadam, H. (2002) Biostratigraphy Study of the Ilam and Gurpi Formations Based on Planktonic Foraminifera in SE of Shiraz, Iran. Journal of Sciences, Islamic Republic of Iran, 13, 339-356.

[39] Sari, B. (2006) Upper Cretaceous Planktonic Foraminiferal Biostratigraphy of the Bey Dağlari Autochthon in the Korkuteli Area, Western Taurides, Turkey. The Journal of Foraminiferal Research, 36, 241-261. http://dx.doi.org/10.2113/gsjfr.36.3.241

[40] Shafiee Ardestani, M., Vahidinia, M. and Youssef Ali, M. (2011) Biostratigraphy and Foraminiferal Bioevent of the Abderaz Formation (Middle Turonian-Lower Campanian) in Kopeh-Dagh Sedimentary Basin, Northeastern Iran. Egyptian Journal of Paleontology, 11, 1-16.

[41] Kauffman, E.G., kennedy, W.J. and Wood, C.J. (1996) The Coniacian Stage and Substage Boundaries. Bulletin de l'Institut Royal des Sciences Naturelles de Belgique, Sciences de la Terre, 66, 81-94.

[42] Ardestani, M.S., Vahidinia, M., Sadeghi, A., Arz, J.A. and Dochev, D. (2012) Integrated Biostratigraphy of the Upper Cretaceous Abderaz Formation of the East Kopet Dagh Basin (NE Iran), Geologica Balcanica, 41, 21-37.

[43] Robaszynski, F., González Donoso, J.M., Linares, D., Amédro, F., Caron, M., Dupuis, C., Dhondt, A.V. and Gartner, S. (2000) Le Crétacé supérieur de la région de Kalaat Senan, Tunisie Centrale. Lithobiostratigraphie intégrée: Zones d'ammonites, de foraminiféres planctoniques et de nannofossiles du Turonien supérieur au Maastrichtien. Bulletin des Centres de Recherches Exploration-Production Elf-Aquitaine, 22, 359-490.

[44] Premoli-Silva, I. and Sliter, W.V. (1981) Cretaceous Planktonic Foraminifers from the Nauru Basin, Leg 61, Site 462 Western Equatorial Pacific. Initial Reports of the Deep Sea Drilling Project, 61, 423-437. http://dx.doi.org/10.2973/dsdp.proc.61.104.1981

[45] Gebhardt, H. (2001) Calcareous Nannofossils from the Nkalagu Formation Type Locality (Middle Turonian to Coniacian, Southern Nigeria): Biostratigraphy and Palaeo-Ecologic Implications. Journal of African Earth Sciences, 32, 391402.

[46] Birkelund, T., Hancock, J.M., Hart, M.B., Rawson, P.F., Remane, J., Robaszynski, F., Schmid, F. and Surlyk, F. (1984) Cretaceous Stage Boundaries-Proposals. Bulletin of the Geological Society of Denmark, 33, 3-20.

[47] Marks, P. (1984) Proposal for the Recognition of Boundaries between Cretaceous Stages by Means of Planktonic Foraminiferal Biostratigraphy. Bulletin of the Geological Society of Denmark, 33, 163-169.

[48] Koutsoukos, E.A.M. and Bengtson, P. (1993) Towards an Integrated Biostratigraphy of the Upper Aptian-Maastrichtian of the Sergipe Basin, Brazil. Documents des Laboratoires de Géologie de Lyon, 125, 241-262.

[49] Walaszczyk. I. and Wood, C.J. (2008) Turonian-Coniacian Boundary; Definition, Recognition and Stratotype Problems. International Geological Congress, Oslo, 6-14 August 2008.

[50] Wood, C.J., Ernst, G. and Rasemann, G. (1984) The Turonian-Coniacian Stage Boundary in Lower Saxony (Germany) and Adjacent Areas: The Salzgitter-Salder Quarry as a Proposed International Standard Section. Bulletin of the Geological Society of Denmark, 33, 225-238.

[51] Walaszczyk, I. and Wood, C.J. (1999) Inoceramids and Biostratigraphy at the Turonian/Coniacian Boundary; Based on the Salzgitter-Salder Quarry, Lower Saxony, Germany and the Sחupia Nadbrze"na Section, Central Poland. Acta Geologica Polonica, 48, 395-434.

[52] Walaszczyk, I. and Wood, C.J. (2000) Inoceramid Bivalves at the Turonian/Coniacian Boundary: Biostratigraphy, Events and Diversity Trends. Acta Geologica Polonica, 50, 421-430.

[53] Wood, C.J., Walaszczyk, I., Mortimore, R.N. and Woods, M.A. (2004) New Observations on the Inoceramid Biostratigraphy of the Higher Part of the Upper Turonian and the Turonian-Coniacian Boundary Transition in Poland, Germany and the UK. Acta Geologica Polonica, 54, 541-549.

[54] Dochev, D. (2006) New Biostratigraphic Data Based on Inoceramid Bivalves from the Interval Upper Turonian-Coniacian in Breznik, West Srednogorie Mountains, Bulgaria. Geosciences, 61-64.

[55] Wolff, T., Grieger, B., Hale, W., Dürkoop, A., Mulitza, S., Pätzold, J. and Wefer, G. (1999) On the Reconstruction of Paleosalinites. In: Fischer, G. and Wefer, G., Eds., Use of Proxies in Paleoceanography: Examples from the South Atlantic, Springer-Verlag, Berlin, 207-228. http://dx.doi.org/10.1007/978-3-642-58646-0_8

[56] Gallemí, J., López, G., Martínez, R. and Pons, J.M. (2007) Macrofauna of the Cantera de Margas Section, Olazagutia: 
Coniacian/Santonian Boundary, Navarro-Cantabrian Basin, Northern Spain. Cretaceous Research, 28, 5-17. http://dx.doi.org/10.1016/j.cretres.2006.05.014

[57] Hampton, M.J., Bailey, H.W., Gallagher, L.T., Mortimore, R.N. and Wood, C.J. (2007) The Biostratigraphy of Seaford Head, Sussex, Southern England; an International Reference Section for the Basal Boundaries for the Santonian and Campanian Stages in Chalk Facies. Cretaceous Research, 28, 46-60. http://dx.doi.org/10.1016/j.cretres.2006.05.025

[58] Ion, J. and Szasz, L. (1994) Biostratigraphy of the Upper Cretaceous of Romania. Cretaceous Research, 15, 59-87. http://dx.doi.org/10.1006/cres.1994.1003

[59] Kopaevich, L.F., Beniamovski, V.N. and Sadekov, A.Y. (2007) Middle Coniacian-Santonian Foraminiferal Bioevents around the Mangyshlak Peninsula and Russian Platform. Cretaceous Research, 28, 108-118. http://dx.doi.org/10.1016/j.cretres.2006.05.018

[60] Lamolda, M.A. and Hancock, J.M. (1996) The Santonian Stage and Substages. Bulletin de l'Institut Royal des Sciences Naturelles de Belgique, Sciences de la Terre, 66, 95-102.

[61] Melinte, M.C. and Lamolda, M.A. (2007) Calcareous Nannofossil Biostratigraphy of the Coniacian/Santonian Boundary Interval in Romania and Comparison with Other European Regions. Cretaceous Research, 28, 119-127. http://dx.doi.org/10.1016/j.cretres.2006.05.021

[62] Peryt, D. and Lamolda, M.A. (2007) Neoflabellinids (Benthic Foraminifers) from the Upper Coniacian and Lower Santonian at Olazagutia, Navarra Province, Spain; Taxonomy and Correlation Potential. Cretaceous Research, 28, 3036. http://dx.doi.org/10.1016/j.cretres.2006.05.022

\section{Submit or recommend next manuscript to SCIRP and we will provide best service for you:}

Accepting pre-submission inquiries through Email, Facebook, LinkedIn, Twitter, etc.

A wide selection of journals (inclusive of 9 subjects, more than 200 journals)

Providing 24-hour high-quality service

User-friendly online submission system

Fair and swift peer-review system

Efficient typesetting and proofreading procedure

Display of the result of downloads and visits, as well as the number of cited articles

Maximum dissemination of your research work

Submit your manuscript at: http://papersubmission.scirp.org/ 